DOI https://doi.org/10.30525/978-9934-26-046-9-21

\title{
РОЗРОБКА ПЛУГА-КАРТОПЛЕКОПАЧА 3 АКТИВНИМ РОБОЧИМ ОРГАНОМ
}

\author{
Головатюк А. А. \\ кандидат сільськогосподарських наук, доиент, \\ дочент кафедри агроінженерії \\ Уманський національний університет садівництва \\ Кравченко В. В. \\ кандидат технічних наук, \\ дочент кафедри агроінженеріі \\ Уманський національний університет садівництва \\ Петриченко Є. А. \\ кандидат технічних наук, \\ старший викладач кафедри агроінженеріі

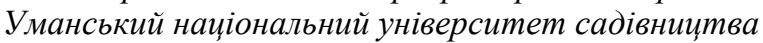 \\ м. Умань, Черкаська область, Украӥна
}

Україна знаходиться в десятці країн в світі по виробництву картоплі. Тому механізація технологічних процесів пов'язаних з іiі збиранням та переробкою $є$ надзвичайно важливим завданням.

Картопля $є$ продуктом 3 високою вразливістю до пошкоджень, що накладає підвищені вимоги до якості збиральних робіт $[1$, c. $73 ; 9$, с. 109$]$.

Збирання картоплі $є$ доволі енергоємним процесом: копач повинен підкопати рядок картоплі в середньому на глибину до 20 см, подрібнити і відсіяти грунт, розділити бадилля та бульби. При цьому, в підрізаному шарі грунту, маса бульб складає лише 1-3\%. Щоб виділити 4-6 кг бульб, машина повинна подрібнити і відсіяти до 200 кг/с грунту [6, с. 112]. За агротехнічними вимогами картоплезбиральні машини повинні викопувати не менш як $97-98 \%$ врожаю, пошкодження бульб не повинно перевищувати $3-5 \%$, а чистота зібраних бульб не менше $80 \%$ [4, с. 57].

Суттєва частка від загального виробництва картоплі в Україні припадає на невеликі фермерські господарства, тому розробка картоплекопальних машин для агрегатування 3 тракторами малої 
потужності, які здатні виконувати основні операції їі збирання викопування і сепарацію є актуальним завданням [9, с. 109].

Найбільш поширеними конструкціями копачів в даному сегменті виробництва $\epsilon$ моделі з однорядним або дворядним пасивним корпусом та приєднаними до нього прутками. Вони утворюють пласку або хвилясту поверхню, завдяки якій домішки грунту частково просіюються, а бульби вкладаються на поверхню рядка для подальшого підбирання.

Однак, відомо, що надання плоскоріжучому робочому органу коливально-поступального руху сприяє зниженню тягового опору грунтообробної машини [2, с. 430]. Тому використання плугакартоплекопача 3 активним робочим органом покращить його експлуатаційні показники за рахунок зниження тягового опору.

Метою досліджень є розробити, виготовити та експериментально дослідити картоплекопач 3 вібруючим робочим органом для викопування бульб 3 меншими енергозатратами та підвищеними якісними показниками збирання.

Розроблений навісний чотирьохрядний картоплекопач призначений для роботи на всіх типах грунтів (рис. 1). Агрегатується 3 тракторами тягового класу 0,6-1,4 кН [5 с. $37 ; 7 ; 8]$.

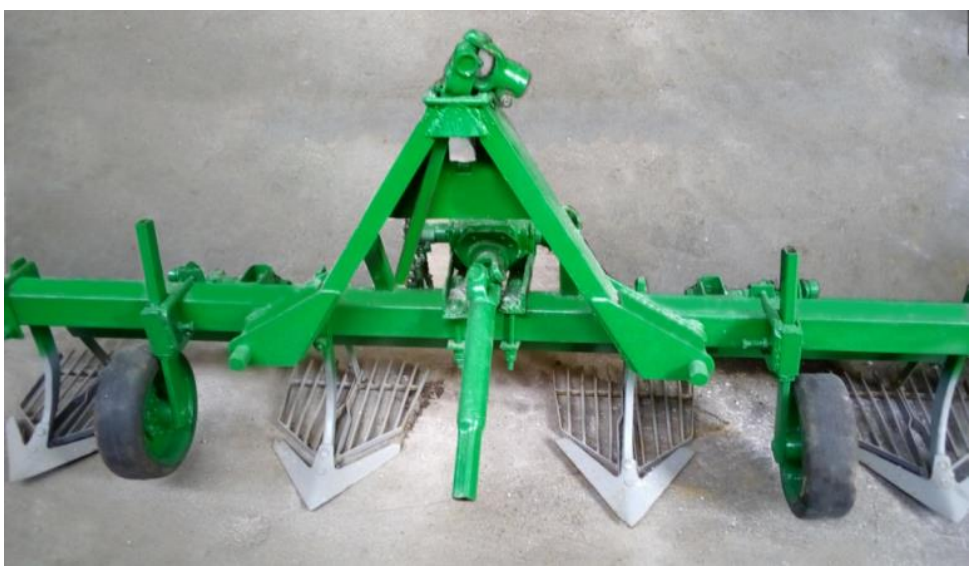

\section{Рис. 1. Розроблений навісний чотирьохрядний картоплекопач}

Плуг-картоплекопач 3 активними робочими органами (рис. 2.) складається із зчіпного пристрою 1, вхідного карданного валу редуктора 2, редуктора 3 , ланцюгової передачі 4, рами зчіпного устрою 5 , 88 
опорних коліс 6 , валу кривошипа 7 , опорних підшипників 8 , кривошипа 9, шатуна 10 , вібраційної планки 11 , рами 12 , плоскорізу 13 , вібраційної решітки 14, шатуна вібраційної планки і вібраційної решітки 15.

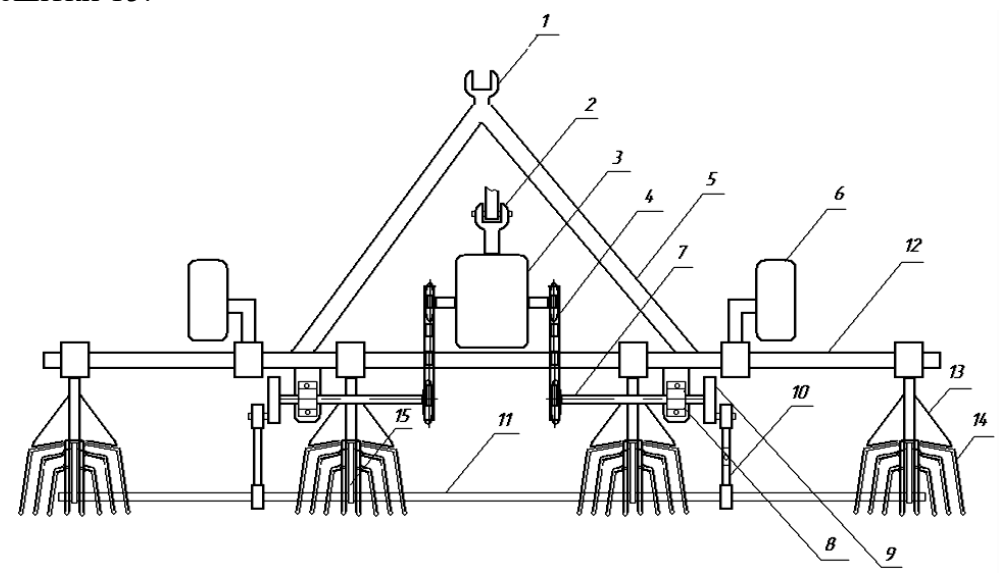

Рис. 2. Конструкція плуга-картоплекопача 3 активними робочими органами

Робота агрегату з вібраційним плугом-картоплекопачем відбувається наступним чином: при русі трактора по міжряддях, крутний момент від валу відбору потужності трактора передається через карданну передачу, редуктор 3 , ланцюгову передачу 4, кривошип 9, шатун 10 та шарніри 16 на вібраційну решітку 14 плоскорізу 13. Під час обертання кривошипу 9 решітка 14 здійснює вібраційні рухи і звільняє від грунту підкопані плоскорізом 13 картоплини, які потім переміщуються з решітки на поверхню грунту.

Використання розробленої машини буде сприяти зменшенню енергоємності процесу збирання картоплі з одночасним покращення таких якісних показників роботи як кількість викопаних бульб, рівень пошкодження бульб під час збирання та якість очищення бульб від грунту.

\section{Література:}

1. Буняк, Н.М. Економічна ефективність виробництва та реалізації картоплі. Вісник аграрної науки. 2002. №2. С. 73-75.

2. Ветохін В.І., Кутя П.О. Проектування та результати випробувань робочого органу для глибокого розпушення міжрядь цукрових 
буряків. Конструювання, виробництво та експлуатація сільськогосп. машин: Загальнодержавний міжвідомчий наук. 2009. Вип. 39. C. $423-433$.

3. Гевко, Р.Б., Синій С.В., Гундзик О.В. Підвищення технікоекономічних показників машин для збирання картоплі. Украӥнський журнал прикладної економіки. 2016. Том 1, № 1. С. 39-49.

4. Грушевський С.М. Аналіз сучасних технологій вирощування i збирання картоплі. Збірник наукових пращь Подільського державного аграрного-технічного університету. 2016. № 24, Ч. 2. С. 55-62.

5. Розробка вібраційного плуга-каотоплекопача 3 активними робочими органами та шляхи покращення його експлуатаційних показників / Мелентьєв О.Б. та ін. Вісник Украӥнського відділення Міжнародної академії аграрної освіти. 2018. № 6. С. 28-47.

6. Марченко В., Ружило 3., Сиволапов В. Агротехніка та механізація збирання картоплі. Пропозиція : укр. журн. з питань агробізнесу. 2009. № 9. С. 112-117.

7. Плоскоріз-картоплекопач 3 активним робочим органом : пат. 106036 Україна : МПК А01В17/00. №u 201510805; заявл. 05.11.2015 ; опубл. 11.04.2016, Бюл. № 7.

8. Вібраційний плуг-картоплекопач : пат. 106037 Україна : МПК А01B17/00. №u 201510806; заявл. 06.11.2015 ; опубл. 11.01.2016, Бюл. № 16.

9. Ходаківський, С.І., Положенець В.М., Чуб Д.В. Виробництво та споживання картоплі. Економіка АПК. 2006. №7. С. 109-111. 